\title{
Gavin Jones, Failure and the American Writer, A
}

\section{Literary History}

New York, Cambridge University Press, Cambridge Studies in American

Literature and Culture, 2014

\section{Stéphanie Carrez}

\section{(2) OpenEdition}

Electronic version

URL: https://journals.openedition.org/transatlantica/7199

DOI: 10.4000/transatlantica.7199

ISSN: 1765-2766

Publisher

Association française d'Etudes Américaines (AFEA)

Electronic reference

Stéphanie Carrez, "Gavin Jones, Failure and the American Writer, A Literary History", Transatlantica

[Online], 2 | 2014, Online since 19 March 2015, connection on 05 February 2023. URL: http:// journals.openedition.org/transatlantica/7199; DOI: https://doi.org/10.4000/transatlantica.7199

This text was automatically generated on 5 February 2023.

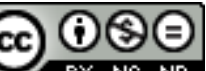

Creative Commons - Attribution-NonCommercial-NoDerivatives 4.0 International - CC BY-NC-ND 4.0 https://creativecommons.org/licenses/by-nc-nd/4.0/ 


\title{
Gavin Jones, Failure and the American Writer, A Literary History
}

New York, Cambridge University Press, Cambridge Studies in American Literature and Culture, 2014

\author{
Stéphanie Carrez
}

\section{REFERENCES}

JONES, Gavin, Failure and the American Writer, A Literary History, New York, Cambridge University Press, Cambridge Studies in American Literature and Culture, 2014, 191 pages, ISBN 9781107662179, 24.99 dollars.

1 Gavin Jones aptly chose "A Literary History" as a subtitle to his Failure and the American Writer, published in 2014 by Cambridge University Press. He indeed proposes a series of insightful readings of the writings of a number of canonical American authors, from Washington Irving to Henry Adams, using the idea of "failure" as a unifying theme and guideline to provide the reader with an original presentation of nineteenth-century literature. Gavin Jones often focuses on the editorial history of the works he discusses here, either to remind his reader of the difficult "material conditions of authorship" (53) or to examine the revisions they introduced. He explores the formal and structural failures he identifies in the works of these celebrated authors and aims at showing how these literary texts reveal something about the concept of failure, "a difficult, even taboo idea that often becomes hidden in the culture at large" (159).

2 In an introduction centred on the reading of the chapter entitled "Failure" in Henry Adams's The Education of Henry Adams, Gavin Jones posits as a central idea that twentieth-century modernist fascination with failure finds its roots in a nineteenth century itself perceived as marred by flaws and in which "the nightmare of a failed democratic experiment [...] came to haunt the American dream of success" (20). Gavin Jones finds in Henry Adams's retrospective vision of the nineteenth century as a "catastrophic" (1) or "failed century" (2) a rationale to explore what he calls "a 
productive fracture or fault that runs through the bedrock of nineteenth-century American literature" (2).

3 In the first chapter, Gavin Jones proposes to read Edgar Allan Poe's "The Fall of the House of Usher" against the backdrop of the financial Panic of 1837 and the collapse of real estate values (21), interpreting the gothic imagery as an embodiment of "the horror of social breakdown" (22). He then turns to the study of two of Poe's stories involving balloon travel, as "the balloon became a prominent metaphor for the unstable economy" at the time (24), convincingly arguing that their form as literary hoaxes and their very failure at duping the readers lead us to question "a flawed system of credibility" (29). After discussing "Ulalume," a poem "hovering between meaning and nonsense" (32), Gavin Jones concludes that Poe's readers are constantly confronted with "problems of inconclusive interpretation" (22) and that the text thus "performs the dread of personal failure as a reading experience" (23). For Poe, failure represents "a kind of feeling embodied in a problem of interpretation" (65).

The second chapter on Herman Melville opens on the idea that Pierre "was a book designed to fail" (36) and that "the exposure of formal flaws" is "a sign that Melville's novel is a study in failure" (37). As a starting point, Gavin Jones recalls the "theory of failure" devised in "Hawthorne and His Mosses," in which failure is presented "as a necessity, if not a condition of genius itself" (38). On the other hand, he considers that Melville presents "fallibility as a condition of man's very being" (46), and thus that "failure must be an essential part of any artistic effort to grasp and convey that human experience" (50). According to Gavin Jones, this conception of failure is not to be understood only in religious terms: "ambiguity is the formal correlative of failure" as "the corrosive acid of democracy sweeps Pierre from his secure foundations" (48) and results in "his intellectual fall into uncertainty" (49). Gavin Jones then focuses on "the self-referential nature of the novel's comments on the profession of authorship" (52) and on the difficulties Melville had according to him to maintain "his ironic distance from Pierre and his situation" (54) to finally conclude that "an ironic novel about literary failure is no alternative to mediocrity" (56) and that "the failure in Pierre is the kind that fails" (59).

5 The chapter devoted to Henry David Thoreau opens on the classical images of the author as "a symbol of failed ambition" (60) and of his experiment in Walden as a "failure to settle down into a conventionally productive life" (63). Gavin Jones also recalls Emerson's criticism of Thoreau's "obsessive detailing of the environment" as an "epistemological failure to add things up to mean more than the sum of the parts" (67). In Walden, Thoreau builds upon analogy, "the simple machine of transcendentalist style" (62), and uses anecdotes "to create additional value from a small moment of natural observation" (65), which is to be related to his interest in economy. However, Gavin Jones argues that since the anecdote "consistently fails to become coherent analogy" (72), Thoreau questions "the power of analogy itself to generate meaning from experience" and "inscribes literature with a primary power to embody failure as a fundamental facet of our knowledge of the world" (74).

In chapter four, Gavin Jones examines "Crane's interest in the nature and conditions of heroic action" (78). According to him, Stephen Crane's stories "resonated with a cultural anxiety that the Civil War was a source of shame, not pride" (77) but more importantly they are about "the mid-1890s and the overpowering forces of industrialization then coming into being" (83). Henry's story in The Red Badge of Courage 
is then read as "the biography of the Gilded Age itself" with "its shameful failures glossed over with false images of tranquillity" (93). Drawing upon the study of sociologist Erving Goffman on social stigma, Gavin Jones also suggests that Stephen Crane explores "a shameful gap between virtual and actual social identity" (80) using free indirect discourse and irony. Both contribute to shaping "Henry's attempt to adapt to failure by constructing his heroism" (84). The moments when "this ironic technique itself seems to falter" at the end of the story (85) correspond to the breaking down of "the binary of authentic and inauthentic heroism" (86), thus "demonstrating the flawed cultural construction of authentic experience" (99) and addressing the failure of American realism "to deliver on its representational promises" (78).

7 Chapter five centers on the study of Mark Twain's Pudd'nhead Wilson and of the story entitled "Those Extraordinary Twins" which was initially part of this novel. Gavin Jones analyses the displacement that occurred from one version of the story to another and "the crisis of character it generates" (101). The difference between minor and major characters is upset, which can be read "in light of America's racial logic, based not on relative position on a social scale but on absolute distinctions between those who are socially alive and those who are socially dead" (102). More importantly according to him, it reveals a failure in "the author's management of his material" as "the narrative's seams begin to show" (104). He adds that in Mark Twain, "these formal failures become recursively about themselves" and "the failure of personal integrity [is] shaped by the failure of authorial control" (109).

8 In the chapter dealing with Sarah Orne Jewett, Gavin Jones discusses her often remarked inability to "construct a coherent plot" (112), which he prefers interpreting as a process of "active reduction" (115) enabling her to "refuse to engage the historical sense" that Paul Ricœur "associates the plotted story with" (130). Presenting the end of the nineteenth century as "an era obsessed with plots of decline" (114) in which plots can be construed as "equivalent to determinism" (115) or even, in the case of Edith Wharton's House of Mirth, as "deeply complicit with the social forces that exclude Lily from any republic of the spirit" (116), Gavin Jones posits that her stories focus on the "everyday being of things that resists plot-like interconnectedness or developments over time" (119). Her specific use of framing allows her to achieve "a stable condition of limitation defined against a vastness of perspective" (142) and her regionalist writings thus exemplify "a contentment in sorrow and a comfort in isolation" (132).

9 The last chapter is devoted to a study of Henry James and of "his style's failure to express directly" (134). After mentioning the comparison between "his hyperbolic and foggy style" and "a hippopotamus" devised by H. G. Wells (136), Gavin Jones first focuses on "The Beast of the Jungle" to show how failure for the character of Marcher is "a consequence of great attention being paid to the disproportionately insignificant," which "is also fundamentally the experience of reading James" (143). He then turns to an analysis of The Ambassadors, presenting Strether's failure as "a fundamental process of consciousness, a recognition of the necessity of continual error and correction, fragmentation and repair, mistake and revision" (151), to finally conclude that style in Henry James's texts becomes "the always inadequate medium driven by failure in its rage to represent" (152).

10 On the whole, Gavin Jones provides the reader with stimulating and carefully documented readings while at the same time delineating a complex and engaging definition of failure through the connections he establishes among the different 
authors he chose to study. The form adopted to present his findings, with chapters devoted to "quite unique, often very personal cases" (159), as well as his project to locate failure "in the shuttling between specific social problems, ideological contradictions, and historical crises on the one hand, and the anxieties of literary creation and identity on the other" (158), are inherently fraught with the danger of fragmentation. As a consequence, the very extent to which these readings are successful also points to their limits, in that the parallels drawn between the various texts might occasionally appear as slightly artificial and the unifying concept of "failure" is at times somewhat stretched, for example when Gavin Jones implies that "catastrophe" can be construed as "the intensification of failure" (6). However, his book will be of great interest to those who want to explore the nether side of the rise to prominence of the United States in the nineteenth century through a series of masterly conducted cultural studies analyses which offer an innovative vision of well-known and often discussed authors.

INDEX

Subjects: Recensions

\section{AUTHORS}

\section{STÉPHANIE CARREZ}

Université de Tours François Rabelais 